\title{
Waste to Energy, Wasting Resources and Livelihoods
}

\author{
Jutta Gutberlet \\ Department of Geography, University of Victoria \\ Canada
}

\section{Introduction}

Not recovering the material embedded in solid waste means wasting resources and thus reinforcing the pressure to further extract natural resources for the manufacturing of new products. Industrial ecology, life cycle analysis, material flow analysis, ecological footprint and other approaches and concepts have long ago already demonstrated the necessity and possibilities of reintegrating recyclable materials into production flows, reducing the waste of resources and thus sparing the environment. Far too often however, business is done as usual and the status quo of production and consumption is not altered significantly.

The prevailing perceptions of waste are still based on the understanding that waste is something worthless, unused or has ceased to be useful for human purpose. The word waste comes from the Latin vastus, meaning unoccupied or desolate and is akin to the Latin vanus (empty or vain) (Lynch, 1990). Originally waste meant something useless and hostile to humans, to be ignored and discarded. Products and packaging usually have a defined lifespan. Sometimes the product life is shortened for the purpose of inducing larger consumption rates. Nor producer, nor consumer are generally concerned about the final destination of these materials. However, with reuse and recycling these materials again become potential resources. Legislation implementing reverse logistics has the potential to alter the established wasteful cycles. Incineration to recover the energy from waste can not be considered a sustainable recycling practice, since it is not an energy efficient process and once burnt the resources are gone for ever.

The statistics evidence that we live in a time of waste explosion. Never has humanity generated so much refuse during production and garbage after consumption as in current times. It is estimated, for example, that globally, 20-50 million tons of E-Waste, the newest category of waste, which includes electronic and electric equipment, are discarded annually (Ongondoa et al., 2011). The authors confirm that the penetration of electronic equipment in a number of countries in the global South is approaching the level of industrialized countries. In Brazil the increasing generation of E-Waste is becoming a noticeable concern. Most of this waste comes from obsolete mobile phones, telephones, TVs, computers, radios, washing machines, refrigerators and freezers. In 2006, the per capita E-Waste rate in Brazil already stood at $2.6 \mathrm{~kg}$, compared to the global average of $1 \mathrm{~kg} /$ per person/ per year (Rocha, 2009).

Even remote rural towns, almost everywhere, have to deal with increasing generation of waste and growing complexity of the waste composition. At the same time household 
garbage has become more industrialized, more toxic and less biodegradable. With the advent of globalised mass consumption, coupled with the lack of adequate spaces to discard these materials, particularly in city regions, Governments, producers and consumers are under pressure to find adequate solutions to the problems created by solid waste.

In the forefront of the current waste management debate is the promotion of new technologies for waste treatment. Less attention is given to considerations that suggest resource economy, reuse, recycling and changes in production, consumption and lifestyles to generate less waste at first. Recommendations that question the continuous, growth oriented economic development and consumption patterns are less popular and usually silenced in order to maintain the status quo. Marxist perspectives underline the fact that capitalism requires a steady acceleration of wasting, discarding and abandonment, in order to keep a scarcity of goods. Scarcity coupled with an artificial inflation of consumer desires, increases the throughput of material in our system, and thus maintains the rate of profit in the face of its progressive tendency to fall.

Solid waste incineration is propagated by business and the media as an efficient management solution, because of the rapid handling of the discarded materials, the diminished need for new landfills and the generation of energy as a by-product. Yet, the environmental and social dimensions of this technological approach to waste often remain unconsidered. Social and environmental injustice may arise from locating these technologies and from displacing the workers who already make a living through resource recovery. Deliberating authorities often overlook the wider implications from deviating recyclable materials away from the recycling sector.

This chapter will analyze the recent emergence of 'waste for energy' (WfE) proposals in Brazil. The discussion will consider particularly the social perspectives related to waste management decisions, looking at existing informal and organized recycling schemes. The government supported selective waste collection and recycling initiatives in the cities of Diadema and Londrina will showcase viable solutions in integrated waste management. Expensive 'waste to energy' schemes are considered unsustainable for generating environmental harm and for perpetuating the waste of natural and human resources.

\subsection{Trends in household waste generation}

"People consume leisure, space and time as if our lives were simply an eating up and a throwing away [...] it is clear that capitalism, once it is connected to the mass market, is motivated to increase consumption" (Lynch, 1990, p. 148).

Unsustainable lifestyles have permitted and motivated ruthless natural resource extraction with disastrous results for the environment, and in particular for indigenous and traditional communities. Media reports on new environmental and social impacts from mining, fishing, forestry, cattle ranching, industrial activities, transportation, tourism, etc. reach us every day through Internet, radio, television, theatre, art, film, music and written sources. The links between resource over-exploitation and environmental disasters (culminating in climate change) seem direct and clear and yet are ignored or denied. In fact, most societies consume more resources than a sustainable living would allow. The prevailing western economic development model has allowed for unprecedented accumulation of wealth while the number of socially and economically excluded people continues on the rise. Naomi Klein evidences these perverse facets of economic growth based on the exploitation of nature and society in her book 'The shock doctrine' (Klein, 2008). The price we pay in terms of losses in biodiversity and cultural diversity is high, just to maintain, further disseminate and 
accelerate the status quo of mass consumption and unsustainable lifestyles. The problems generated by increasing waste quantities are ubiquitous.

The quantity of solid waste, in Europe and North America in particular, has increased in close relation to economic growth, over the past decades, attested by the growing solid waste quantities along with increases in Gross Domestic Products (GDPs). A Swedish study from Sjöström and Östblom (2010), for example, mentions a total quantity of municipal waste per capita increase of 29\% in North America, 35\% in OECD countries, and $54 \%$ in the EU15 between 1980 and 2005.

Packaging magnifies the task of household disposal because of its bulky proportions and its mixture with decomposable garbage. For the sake of convenience and the prevention of spoilage and disease products are wrapped more than ever, often using materials, which do not decompose, are toxic, or are still difficult to recycle.

Although household waste manifests only a fraction of the solid waste generated, its reduction can be key in promoting a paradigm shift towards more sustainable production and consumption patterns. Construction waste, industrial waste, mining waste, and agricultural waste are also linked to consumption and lifestyles. In 2005, the UK produced approximately 46.4 million tons of household and similar waste with $60 \%$ of this landfilled, $34 \%$ recycled and $6 \%$ incinerated. Only $11 \%$ of the estimated waste was household waste, compared to $36 \%$ construction and demolition, $28 \%$ mining and quarrying, $10 \%$ industrial, $13 \%$ commercial waste, and less than $1 \%$ agricultural and sewage waste (Department for Environment, Food and Rural Affairs [DEFRA], 2006).

Despite the prevailing waste of resources, there are also initiatives concerned with the reduction and ultimately the generation of zero waste. Banning plastic bags is often one of the first actions promoted by local governments and some business towards reducing plastic waste and, although important, only targets the tip of the iceberg. Lifestyle changes suggested under the voluntary simplicity initiative are perceived as another form of individuals impacting these developments. These measures are all important, however they need to come together with policy instruments in order to reduce waste intensities and to alter the final destination of waste.

\subsection{Trends in municipal solid waste management}

Although worldwide landfilling is on average still the most widespread form of waste disposal, more and more cities are moving away from waste deposits towards recycling and incineration. In India almost $90 \%$ of the collected household waste is still deposited at uncontrolled sites (Talyan et al., 2008). In Turkey too, dumping solid waste on open sites is still the prevailing method, followed by sanitary landfills (Agdag, 2009; Turan et al., 2009). The final destination in the United Kingdom, Canada and the United States for over $50 \%$ of the household waste is still the controlled landfill, however here too the trend goes towards increased recycling. Sweden is one of the few countries, which already has a reduced percentage of waste disposed at landfills; and it is also one of the countries with the highest waste incineration rate (Persson, 2006).

Less generation of waste, more material recovery, energy from waste and much less landfills seems to be the guiding principles in many European countries (DEFRA, 2007). Within recent decades, one of the major arguments for waste incineration in the global North has been the energy generation from solid waste and the potential fossil fuel saving. The following table summarizes some country's waste incineration capacities (Table 1). 
Similar developments are occurring in North America. In the US for example already $12.6 \%$ of the household waste was incinerated in 2007 (Vyhnak, 2008). Japan, South Korea, Taiwan and Singapore are the Asian countries with the largest number of incinerators (Gohlke \& Martin, 2007; Bai \& Sutanto, 2002). In Latin America the number of incinerators is still small and addresses mainly hospital and industrial waste. In the 1970s and early 1980s municipal governments in São Paulo and Buenos Aires had contemplated the expansion of incinerators for household waste, however, at that time social mobilization and the high cost of this technology prevented its establishment. Waste incineration has now re-emerged in Brazil and in other countries in Latin America as 'waste for energy' plants.

$\begin{array}{lcr}\text { Country } & \text { Number of establishments } & \text { Tons/year } \\ \text { Holland } & 11 & 488,000 \\ \text { UK } & 19 & 266,000 \\ \text { Sweden } & 31 & 136,000 \\ \text { France } & 210 & 132,000 \\ \text { Italy } & 32 & 91,000\end{array}$

Table 1. WfE establishments in some European countries. Source: Longden et al., 2007; European Environmental Agency [EEA], 2009).

How do cities in Brazil cope with the rapidly mounting quantities of discarded material? In Brazil $25.5 \%$ of the municipalities still dump their waste on uncontrolled landfills, while another 19.6\% deposits the waste on controlled landfills (Associação Brasileira de Empresas de Limpeza Pública e Resíduos Especiais [ABRELPE], 2007). Officially the recycling rate in Brazil is still insignificant, with approximately $2 \%$ of the waste being recovered through government supported selective waste collection programs (Brazil, 2009). Throughout Brazil, as well as in other Latin American and Asian countries there are numerous experiences where organized recycling groups engage at different levels with Government in order to perform selective waste collection in their city. In many cases the recyclers have already established a history in the community with door-to-door collection and partnerships with business and industry. It is important to note that the official number for recycling does not include the effort of tens of thousands of informal recyclers working throughout Brazil, as well as in most other countries in the global South. In Brazil, for example, there are between 800,000 to one million informal and organized recyclers (called catadores), according to the national recyclers movement (Movimento Nacional de Catadores de Materiais Recicláveis [MNCR], 2010). These people make a livelihood from resource recovery, contribute to resource savings, and diminish environmental hazards by redirecting the materials.

Uncontrolled landfills, such as the famous Gramacho landfill in the metropolitan region of Rio de Janeiro, recently portrayed in the award winning movie Waste land and in the documentary 'Beyond Gramacho', are still a reality in some parts of Brazil. With the implantation of the recently approved federal solid waste management law (Law No12.305/2010 - Política Nacional de Resíduos Sólidos), however, the days of uncontrolled landfills are counted until 2014, when all uncontrolled waste dumps need to be eliminated and every city is required to have their waste management plan in place. 
Given the pressure on municipalities to finding adequate forms of waste management, many governments perceive incineration as a quick and simple alternative. Thermal and bio-mechanic treatment of waste is gaining momentum in many parts of Brazil, as municipalities in Latin America and Asia are being offered expensive Waste for Energy technology as a solution to their waste crisis.

\section{Social and economic reflections on Waste for Energy (WfE)}

This section introduces social, environmental, and philosophical questions related to Waste for Energy, without detailing the technical aspects of the various technologies. As discussed earlier there is a tendency in Europe and North America to set up waste for energy plants, supported by specific funding programs and converging energy and waste legislation. In England for example the Energy White Paper (Department of Trade and Industry, 2007) and the Waste Strategy for England (DEFRA, 2007), advocate for waste being a resource to generate biomass fuel as well as heat and power. "Energy from waste is expected to account for $25 \%$ of municipal waste by 2020 compared to $10 \%$ today" (DEFRA, 2007, p. 7). There have already been a number of inter related projects that have facilitated investment in renewable energy and waste infrastructure.

To transform solid waste into energy is an attractive proposal, given the pressure put on governments in terms of achieving greater shares of energy from renewable sources. For example, the EU's target to achieve alternative energy supply is at $20 \%$ by 2020 . Increased recovery of energy from waste is interpreted as a key objective to help reduce greenhouse gas emissions by diverting greater amounts of biodegradable waste away from landfills and by increasing the recovery of energy from waste. In the EU governments have promoted measures to stimulate energy recovery from solid waste. Such measures include the "banding of the Renewables Obligation (' $\left.\mathrm{RO}^{\prime}\right)$, extending enhanced Capital Allowances ('ECAs') to include Solid Recovered Fuel ('SRF') related equipment along with a heightened expectation for energy generated from waste management activity to achieve the most climate change friendly outcome through the use of "CHP' [combined heat and power]" (DEFRA et al., 2009, p. 4).

Recent technology developments see solid waste converted into recovered fuel pellets. These would, for example, be produced locally and transported to large-scale gasification and petrochemical facilities to be used in substitution for diesel or gasoline fuel. The European oil and automotive industries are supportive of WfE technology as a means to meet the current and future bio-fuel directive. Solid waste recovered fuel is "prepared from non-hazardous waste to be utilised for energy recovery in incineration or co-incineration plants..." (DEFRA et al., 2009, p. 9). The critique from environmentalists is usually related to climate change impacts with carbon dioxide generation from these plants and the high costs for this technology. These expenses could be invested in more environmentally sound and climate friendly energy, tackling the problem at the roots.

The examples on energy policy supporting the use of solid waste as 'alternative' fuel in the UK, are representative for the trend in many countries in Europe and North America. Rising prices for fossil fuel over the past decade are often mentioned to justify WfE. Waste fuels are eligible for revenues under the Renewables Obligation and the EU Emissions Trading Scheme. Existing protocols and standards for the use of waste fuels are adjusted to facilitate the options provided by WfE. Particularly climate change and renewable energies legislation consider WfE technology a legitimate form to be funded under Carbon gaining funds. 
Industry has addressed the negative image that is attached to waste incineration by referring to the technology primarily as energy recovery form. The following quote highlights a dominant engineering perspective, failing to understand the larger environmental and social picture. "Waste should be regarded as a fuel rather than something which needs to be treated - Unfortunately, most legislation over recent years has erroneously and dogmatically focused on WfE as waste treatment rather than as energy production, and has attempted to deal with an WfE plant as if it were an incinerator, rather than a power station" (Institution of Mechanical Engineers, n.d., p. 18).

Waste management decisions often favour incineration as a quick and efficient solution and governments assist the process of obtaining local planning consent and licensing implantation for WfE plants as power plants. In addition, there are many other drivers for WfE, including:

- Increasing costs of WfE treatment (and disposal),

- rising energy demands,

- $\quad$ potential to quickly reduce the large volume of waste generated daily,

- understanding that energy can be generated from waste and converted into electricity, erroneously promoted as "green energy",

- reduced costs with workforce,

- $\quad$ potential to receive government revenue or to avoid costs from the use of waste fuels.

The trends observed in countries in the global North are making its way to the countries in the global South. Here the public is usually not well informed about the risks, the costs or alternatives. Multinational concerns and consulting firms approach governments in these countries to showcase the technology and to promote accessible public-private funding schemes for local governments to implement WfE technology. Most often these decision processes happen without ample community awareness and participation.

\subsection{Major concerns with Waste for Energy approaches}

- WfE is not a form of recycling

Solid waste incineration with energy recovery is often referred to as recycling, and is therefore credited with the benefits and the positive image of recycling. However, the term 'recycling' means "recovery and reprocessing of waste materials for use in new products. The basic phases in recycling are the collection of waste materials, their processing or manufacture into new products, and the purchase of those products, which may then themselves be recycled" (Britannica Online Encyclopedia, n.d.). Following this rational, solid waste is understood as renewable resources. However, the resource solid waste is only renewable if recycled. Waste to energy makes it a non-renewable resource.

Furthermore, with WfE the need to adopt a materials flow, a cyclical approach is not met. This technology does not involve a cyclical course, since the material dies with incineration. WfE is considered recycling, however, the final product of this industry is energy, which is a final stage, whereas in material recycling any other product can be recycled at least twice.

- WfE is not a 'green' technology

WfE is often considered a 'green' technology because it reduces potential methane gas emissions, which would be generated at the landfill. However, the incineration process itself also generates greenhouse gas emissions, despite the claim of being a Carbon saving mechanism. 
Depending on the material, on the process and the local circumstances, recycling also results in a net reduction of greenhouse gas emissions, however, with the benefit of also reducing emissions related to new resource extractions. Organic waste recycling and composting though benefit the methane gas reduction at landfills.

- WfE is not energy efficient

Despite WfE not necessarily being energy efficient, in the UK this technology is considered under the Renewable Obligation Certificate (ROC), which is the main support scheme for renewable electricity projects in the UK. It places an obligation on UK suppliers of electricity to source an increasing proportion of their electricity from renewable sources. Ironically WfE falls under this regime. In the UK, combined heat and power plants (CHP) continue to receive $1 \mathrm{ROC} / \mathrm{MWh}$ of electricity generated and Biomass $\mathrm{CHP}$ plants will receive 2 ROCs/MWh (DEFRA et al., 2009).

- Growth oriented WfE

WfE assumes growth in solid waste generation. For example, in the UK the expected increase of $1.5 \%$ per year signifies an arising of 37 million tons of waste in the year 2020 (DEFRA, 2007). Again the proposal of WfE is anchored in a growth-oriented paradigm. In order for WfE to be considered economical al and to meet the continuous increased energy demands, there will have to be an ever-increasing amount of solid waste, which is unsustainable.

- Decisions to implement WfE are usually not participatory

The need to engage with all stakeholders is not met in the case of the recent expansion of this technology in Brazil. Informal and organized recyclers are major stakeholders in waste management and they are excluded from the decision making process.

\subsection{Multinational funding of Waste for Energy}

In the early 1990s the trend of the private sector becoming more independent of government agencies and the public sector becoming more businesslike started to become noticeable (Larkin, 1994). Economic globalization has allowed for the private initiative and particularly large corporations to expand into basic infrastructure and service provision, which until then were generally provided through the government. Municipal waste management was one of the last public sectors to become explored by private capital. During the past few years large-scale technologies such as incineration or automatized selective separation plants have massively entered the waste management market, also in the global South.

Public Private Partnerships (PPP) and Private Funding Initiatives (PFI) are common in the funding of these expensive incineration technologies. PPPs are considered an alternative to full privatization and a solution for municipalities to tackle basic infrastructure and service provision related to water, sewage and waste. Rapidly increasing urban population, following consumption-oriented lifestyles, has generated serious disposal problems in most cities in the global South.

Through PPPs "government and private companies assume co-responsibility and coownership for the delivery of city services ... [and] the advantages of the private sectordynamism, access to finance, knowledge of technologies, managerial efficiency, and entrepreneurial spirit-are combined with the social responsibility, environmental awareness, local knowledge and job generation concerns of the public sector" (Ahmed \& Ali, 2004, p. 471). Ideally this arrangement should improve the efficiency of the entire solid waste management sector. This means, however, that governments can become locked into 
long-term contracts, without the necessary control over strategic decisions or over the quality and price of the service. Whether to partnership with recycling coops or whether to employ or subcontract recyclers in waste management might not be an option for local governments that have contracted out the waste management service.

The new federal solid waste regulation puts municipalities under pressure to invest in appropriate solid waste management. Most of the officially collected solid waste in Brazil is still discarded at uncontrolled waste dumps, causing severe environmental health problems. This situation has to change by 2014, according to the new federal law, when cities are required to have an alternative solution in place for the final solid waste destination. On average $4 \%$ of the municipal budget in Brazil is currently directed towards solid waste management, a figure that is insufficient to make the necessary radical changes away from waste dumping. Hence, PPPs are considered a solution to overcome the solid waste predicament, as suggested by the Brazilian Solid Waste Management Association (Maximo, 2011). In accordance, the federal government has already made available specific credit lines through the two Brazilian banks, BNDS and Caixa Econômica, and by way of specific funds to be used by municipalities to upgrade their solid waste management systems.

\subsection{Social implications of waste incineration}

Although still embryonic, many civil society groups and academics have manifested concerns about WfE technology in many parts of the world. Besides the environmental impacts, with dangerous air pollutants and toxic ashes, waste incineration allows the current unsustainable situation of resource extraction, production, consumption and discarding to be maintained. The switch towards incineration technology does not require the producer or the consumer to change habitual ways of producing and consuming. Once a material is burnt, however, the resource is not renewable any more and will not be able to be used as the same resource. Nevertheless, incineration is advertised as renewable energy, as recycling and even as clean development mechanism. These misconceptions need to be rectified. Waste to Energy technologies terminate the possibility of recycling and therefore reiterate new resource extraction.

Furthermore, there are important social considerations to be made. Incineration does not consider those who are already in the business of making different things with and from solid waste. Many people recover recyclable materials and sometimes add value by transforming them into new products. There are almost endless forms of resource recovery that are labour-intense and provide livelihood opportunities.

Pinto and González (2008) demonstrate that operating selective waste collection still costs approximately twice to three times as much as landfilling household waste. Nevertheless, one ton of household waste placed into a triage centre injects roughly $20 \mathrm{R} \$(12.6 \mathrm{US} \$)^{1}$ into the local economy and generates 2 R\$ (1.26 US\$) in tax benefits (Pinto \& Gonzáles 2008). Selective waste collection generates multiple employment opportunities. Taking the example of the Brazilian city Londrina, recycling creates at least 1 direct work post for 1000 inhabitants considering the collection, separation and commercialization of the recyclables. Here the recyclers earn approximately 2 Minimum Salaries (650 US\$), which is more than organized recyclers make in most cities in Brazil. In addition, numerous jobs are created indirectly with the recycling industry and sometimes with adding value to specific

${ }^{1}$ All exchange rates are based on the Daily Currency Converter (21.06.2011) of the Bank of Canada. 
recyclable products (e.g. transforming plastic PET bottles into washing line - experience CoopCent in Diadema) or creating artisanal products from recyclable materials. The following Table 2 provides an example of direct employment through recycling industries in some cities in the metropolitan region of São Paulo. The numbers do not include indirect employment generated through recycling, nor informal business and intermediary activities.

An important concern related to WfE is that with incineration technology, profits don't stay local. As discussed earlier, multinational and large-scale enterprises involved in the technology make the profits, which are mostly transferred into the large centres within the country or abroad.

$\begin{array}{lccc}\text { Municipality } & \begin{array}{c}\text { Recycling } \\ \text { establishments }\end{array} & \text { Employees } & \text { Total population } \\ \text { Diadema } & 7 & 76 & 386,039 \\ \text { Mauá } & 14 & 289 & 417,281 \\ \text { Santo André } & 5 & 45 & 673,914 \\ \text { São Bernardo do Campo } & 8 & 360 & 765,203 \\ \text { São Caetano do Sul } & 2 & 13 & 149,571 \\ \text { Total } & 36 & 783 & 2,392,008\end{array}$

Table 2. Recycling establishments and number of employees. Source: Classificação Nacional de Atividades Econômicas (CNAE), Personal communication Municipality of Diadema, May 2010.

\subsection{Recent experiences with WfE in Brazil}

Many cities in Brazil are facing increased landfill operating costs or are under pressure to close current waste dumps, which are not adequate to the latest legislation changes. Several municipalities in the state of São Paulo are currently in the process of hiring consultant firms to conduct feasibility studies into waste management. The results are often prescribed WfE technology through PPP financing schemes.

The following table below (Table 3) provides some insight into current WfE developments in Brazil. The data does not claim to be complete. The information sheds light on current trends and practices of governments seeking PPPs to fund WfE technology as a waste management option in their municipality or region.

One waste to energy model currently under discussion in Brazil runs under the bizarre name of 'Tyrannosaurus'. Inspired by the pre-historic carnivorous dinosaur this facility is meant to triturate solid waste and then generate fuel. The name hints the voraciousness of the process. In addition, the layout of this animal body suggests the various stages of the facility from receiving the solid waste (through the tail), separating the materials and triturating them (in the trunk of the body) to, finally, processing the fuel (in the head of the animal).

The 'Tyrannosaurus' was acquired in the metropolitan region of Campinas, in the interior of the state São Paulo, from a Finish firm for the cost of 33 million R\$ (almost 21 million US\$). The facility is meant to burn about 1,000 tons of solid waste per day, generating 500 tons of fuel (Granato, 2011). 


\begin{tabular}{|c|c|c|c|}
\hline City & State & Stage of operation & Proposal \\
\hline Brasilia & $\mathrm{DF}$ & & PPP \\
\hline $\begin{array}{l}\text { Campo } \\
\text { Grande }\end{array}$ & $\begin{array}{l}\text { MT } \\
\text { Sul }\end{array}$ & Bidding process initiated (July 2010) & PPP (960,000 R\$) (604,295.-US\$) \\
\hline Unai & MG & $\begin{array}{l}\text { Operating under the name: ("Clean } \\
\text { Nature Project"). }\end{array}$ & $\begin{array}{l}\text { Solid waste to fuel for state iron } \\
\text { smelter and other chemical } \\
\text { industries. }\end{array}$ \\
\hline $\begin{array}{l}\text { Belo } \\
\text { Horizonte } \\
\end{array}$ & MG & $\begin{array}{l}\text { Viability study conducted by Pöyry } \\
\text { (Nov. 2010). }\end{array}$ & PPP \\
\hline $\begin{array}{l}\text { Cabo de Santo } \\
\text { Agostinho }\end{array}$ & PE & $\begin{array}{l}\text { Thermo-electric plant (to be located } \\
\text { in Mata Atlântica protected watershed } \\
\text { (Pirapam- Tejipió rivers). }\end{array}$ & $\begin{array}{l}\text { PPP }(300,000 \mathrm{R} \$)(188,842 .-\mathrm{US} \$) \text {. } \\
\text { Concession } 20 \text { years. Capacity: } \\
2.856 \text { tons/ day to generate } \\
27 \mathrm{MW} / \text { day. }\end{array}$ \\
\hline Rio de Janeiro & RJ & $\begin{array}{l}\text { Pilot plant called 'Usina Verde' } \\
\text { (Green plant) already operating at the } \\
\text { Federal University of RJ, incinerating } \\
\text { 30tons/day. }\end{array}$ & $\begin{array}{l}\text { Ashes are used in floor tile } \\
\text { production and could be used in } \\
\text { agriculture to reduce soil acidity. }\end{array}$ \\
\hline Barueri & SP & $\begin{array}{l}\text { Bidding process opened on: } \\
20.10 .2010\end{array}$ & $\begin{array}{l}\text { PPP (Concession } 30 \text { ys.). } \\
\text { Planned capacity of } 750 \text { tons. To } \\
\text { be installed at the former } \\
\text { landfill. }\end{array}$ \\
\hline São Sebastião & SP & Viability study conducted. & PPP. 6 firms have placed a bid². \\
\hline $\begin{array}{l}\text { São Bernardo } \\
\text { do Campo }\end{array}$ & $\mathrm{SP}$ & $\begin{array}{l}\text { Bidding process concluded. In } \\
\text { process of getting approval. }\end{array}$ & $\begin{array}{l}\text { PPP. }(220,000 \mathrm{R} \$)(138,484 .- \\
\text { US\$). Proposed location at } \\
\text { former waste dump Alvarenga. }\end{array}$ \\
\hline $\begin{array}{l}\text { Ferraz de } \\
\text { Vasconce-los }\end{array}$ & SP & $\begin{array}{l}\text { Consortium of the Upper Tietê river, } \\
\text { in collaboration with Suzano city } \\
\text { (Nov. 2010). }\end{array}$ & $\begin{array}{l}\text { PPP }(200,000 \mathrm{R} \$)(125,894 .- \text { US\$). } \\
\text { Capacity of } 700 \text { tons/day to } \\
\text { generate } 30 \mathrm{MW} / \text { day. }\end{array}$ \\
\hline Santos & SP & $\begin{array}{l}\text { Viability study has been conducted } \\
\text { (July 2010). }\end{array}$ & PPP $(300,000$ R\$) $(188,842 .-$ US\$). \\
\hline Campinas & SP & $\begin{array}{l}\text { Known under the name } \\
\text { 'Tyrannosaurus'. Operating in } \\
\text { Campinas metro area (Sumaré, } \\
\text { Hortolândia, Nova Odessa, } \\
\text { Americana, Sta. Bárbara d'Oeste, } \\
\text { Monte Mor). }\end{array}$ & $\begin{array}{l}\text { PPP }(33,000,000 R \$)(20,772,624 .- \\
\text { US\$). Solid waste to fuel. Burns } \\
\text { about } 1,000 \text { tons of solid } \\
\text { waste/day, generating } \\
500 \text { tons/fuel. }\end{array}$ \\
\hline
\end{tabular}

Table 3. Brazilian municipalities with proposed WfE plants (2010). Sources: Unpublished literature searched on the Internet (last accessed 28.03.2011).

2 WfE: 1.) EMAE 2.) Keppel Seghers, Singapure, 3.) Consortium AEMA / FAIRWAY / SENER, multinational 4.) HERHOF / GPI, Germany, 5.) LIXOLIMPO CONSULTORIA AMBIENTAL, multinational, 6.) DEDINI Indústrias de Base. 


\section{Selective waste collection and recycling}

In cities in Brazil, as in most countries in the global South, a large number of informal recyclers (catadores) collect recyclable material from the garbage. Often the recyclers establish partnerships with households or businesses separating the material for regular pick up. There is no exact record about the number of catadores, nor about the quantities of material that they recover on a daily basis, since the numbers fluctuate significantly over time.

In many municipalities the recyclers are organized in cooperatives or associations and perform selective waste collection in partnership with the local government. The level and continuity of the official support varies among these experiences, from governments simply tolerating the work of the recyclers to remunerating the collection service performed by the catadores. Although governments might have taken important steps to implement inclusive selective waste collection, these programs are often prone to discontinue after election periods. When recycling programs are consolidated within the local community and when public policies protect these cooperative recycling schemes the work is valued and the results are more successful.

In 2010, approximately $8 \%$ of all municipalities in Brazil (443) had established a selective household waste collection, which reflects a steady increase since 1994, when only 81 cities had recycling programs. More than $62 \%$ of these municipalities collaborate with organized recycling cooperatives in the collection and separation of the materials (Compromisso Empresarial para Reciclagem) [CEMPRE], 2010).

The cost for selective waste collection is still 4 times higher than the regular collection costs. Nevertheless this value has been steadily decreasing, from being 10 times more expensive in 1994. There are also very large discrepancies between different cities, with Londrina having the lowest cost per ton of recovered material (7.2 US\$/ton), compared to São Bernardo do Campo (575 US\$/ton) or Florianopolis (389 US\$/ton), for example. Most selective waste collection programs are located in the southeast $(50 \%)$ and in the south $(36 \%)$ of Brazil. The amount of material recovered through official selective waste collection programs varies a lot between each city, with over 3,500 tons/month of recovered materials Londrina is taking the lead, followed by Porto Alegre (2400 tons/month), Curitiba (2228 tons/month) and Brasilia (1327 tons/month) (CEMPRE, 2010).

According to the data promoted by CEMPRE (2010), the average material composition of selective waste collection in Brazil contains approximately $13.3 \%$ of unrecyclable materials. The rest is composed of $39.9 \%$ paper and cardboard, $19.5 \%$ plastics, $11.9 \%$ glass, $5.7 \%$ other recyclable materials, $1.9 \%$ tetrapack (combined plastic, aluminium foil and cardboard), $0.9 \%$ aluminium and $0.2 \%$ electronics. Most of the plastic, $36.2 \%$ comes as mixed material, $27.1 \%$ as PET, $16.9 \%$ as PEAD, $9.7 \%$ as PP, $6.3 \%$ as PVC among other plastics (CEMPRE, 2010).

There are very little experiences targeting formal collection of organic household waste. A pilot study on door-to-door collection of compostable, organic household waste was conducted in the city of Diadema, confirming the potential to generate income and produce rich compost for urban agriculture and gardening activities (Yates \& Gutberlet, 2011a, 2011b). Experiences from Cuba and Argentina underline the possibilities of contributing to food security by collecting and composting clean organic waste from the households (Mougeot, 2005). Further empirical studies are needed to advance this particular form of 
resource recovery, as important contribution towards zero waste, the avoidance of any waste generation. The following two examples showcase the possibilities in terms of inclusive waste management, generating income and recovering valuable resources.

\subsection{The case of Londrina}

Since 2001, Londrina's Reciclando Vidas (Recycling Lifes) program has become a benchmark for selective waste collection in Brazil (Suzuki Lima, 2007). Londrina is located in the state of Paraná, in the south of Brazil. The city services $90 \%$ of its almost 500,000 inhabitants, with an adherence rate of $75 \%$ of the population. In 2010 these numbers translate into $26.6 \%$ of the household waste being recovered through selective collection, separation and recycling. Only $4 \%$ of the material collected in this program is considered unrecyclable, which is particularly low when compared to other municipalities who are struggling with up to $50 \%$ of rejected material. Door-to-door collection allows for a direct contact with the population, a key aspect in improving the quality of the selective waste collection. In Londrina continuous community environmental education performed by the recyclers has reduced the percentage of rejected material from $15 \%$ in 2001 to $4 \%$ in 2005. In addition, here the recyclers work on tables and not on assembly line belts to do the classification, which also contributes to the reduced loss of materials. A study has shown that separating on tables generates approximately $5 \%$ rejected materials, whereas the assembly belt produces between 25 and 30\% rejected materials (Pinto \& González, 2008).

Today approximately 500 catadores work in this local resource recovery program. The city is divided into 33 sectors and has 33 triage centres. In 2011 the recyclers were paid $64.00 \mathrm{R} \$$ (40.29US\$) per ton of commercialized, recycled material by the government for the quantity of material collected. In addition the recyclers receive a monthly amount of 33,000.00 R\$ ( 20,772.-US\$) for the service of selective collection, prolonging the life of the landfill. This value is divided amongst the recyclers according to their work effort. In 2010, the municipality has in addition invested approximately $20,000.00 \mathrm{R} \$(12,589$.-US\$) every month to acquire trucks and electric selective collection carts improving transportation.

Recent numbers demonstrate a steady expansion of the program from 156,927 kg/month collected from 60,000 households in March 2010, to 274,411 kg/month from 71,648 households in July 2010. The material is separated into 25 different categories and sold to the industry. Cardboard, newspapers and other papers make up the largest quantities of the materials collected, followed by broken glass, PET bottles, tetrapak, and thin coloured plastics.

As part of the Sustainable Waste Management Project (PSWM) delegates from the local government and recyclers visited this experience in selective waste collection in Londrina, Paraná. Participants highlighted the existence of a:

- complex and fair payment system of the recyclers performing various tasks in recycling,

- high level of commitment of the local government with the selective collection system,

- consolidation of public policy more than just a government program,

- high level of feasibility of the door-to-door collection system,

- contractual relationship between government and recyclers,

- strong communication system in the community (e.g.: the recycling program offers a *800 number to communicate with the population),

- exemplary transparency and trust between collectors and government,

- $\quad$ high self-esteem of recyclers. 
As possible difficulties the participants identified:

- $\quad$ precariousness in the infrastructure of the triage centres,

- problems in the logistics of integrating with the recycling industry,

- recyclers seem not yet to be fully inserted into the recycling process,

- current shortcomings in the program for occupational health and environmental education.

The experience of Londrina showcases the importance of collaborative policy programs between government, recyclers and community. Good stakeholder integration is crucial for achieving success. Moreover, adequate public policy for integrated waste management must be in place, more than just a selective waste collection program, but continuously and beyond four-year government periods.

\subsection{The case of Diadema}

The city of Diadema is located in the Greater Metropolitan Region of São Paulo, with 370,184 residents in 2010 (Instituto Brasileiro de Geografia e Estatística [IBGE], 2010), covering an area of $30.84 \mathrm{~km}^{2}$. Diadema has the third-highest population density in Brazil, with over 11,000 inhabitants per square kilometre. It is primarily a low to middle-class, industrial city and approximately $25 \%$ of the population is housed in favelas (squatter settlements), which occupy $3.5 \%$ of the municipality. Since only 73,225 people out of the total population of Diadema are economically active in the formal labour market, many residents are threatened by poverty, food insecurity and unemployment. However, Diadema represents a progressive political scenario in Brazil, providing opportunities for participation and political change.

In 2004, the local government initiated the Vida Limpa (Clean Life) program, a city-wide recycling programme that is operated by recycling associations (Gutberlet, 2008a, 2008b). In 2008 there were six fully-functional collection depots established across the city, based on catchment areas. The recyclers organized under the umbrella association of Pacto Ambiental (Environmental Pact). In June 2004, Diadema became the first municipality in the country to support recyclers' associations with an official policy of remuneration. As of 2008, the catadores received $38 \mathrm{R}$ (24 US\$) per ton of material diverted from the landfill, under a municipal partnership memorandum. Remuneration contributes to the average income of $380 \mathrm{R}$ \$ (approximately 239 US\$) per month amongst Vida Limpa catadores (Gutberlet, 2008b). Despite the pro-active policy in place, recyclers in Diadema remain physically and socioeconomically vulnerable, dependant on unstable economic markets.

In 2007 the city generated 7,514 tons of household waste every month, of which $36 \%(2,705$ tons) are inorganic recyclables. In 2007, the program collected more than 44 tons every month. The evaluation of the door to door selective collection, conducted in 2007, highlighted the fact that in some of the neighbourhoods the recyclers only collected the material from those houses contacted initially, which left out a significant part of the households. Furthermore, one of the neighbourhoods, Chico Mendes, had an extremely high level of rejected material (51\%), as a result of low awareness among the population of the program. There was little interaction of the recyclers with the locals to raise the awareness. Most of the other neighbourhoods had a rejection level between 1\% and 11\% (Gutberlet \& Takahashi, 2007). Since then the program has undergone growth and retraction, depending on the level of support received by the local government. Since 2011 the Vida Limpa program also recycles discarded wood and cooking oil and the municipality is currently working on 
the expansion of a pilot project on organic waste for composting and community gardening (Yates \& Gutberlet, 2011a, 2011b).

\section{The new Brazilian federal solid waste legislation}

At the end of 2010, a new federal legislation on waste management (Law \#12.305/2010) was sanctioned. This recent law and the specific legislation piece on basic sanitation (Law \# 11.445/07) establish the overall rules and obligations for solid waste management in the country. In addition, more specific laws, such as the resolution CONAMA (\#316/2002) and specific state legislation deal with the establishment of sound solid waste facilities.

Over the past 11 years the organized recyclers, through the inter-ministerial panel working on solid waste management, have actively been involved in the design of this legislation. There are obviously also other stakeholders involved in the process who defend different interests and are able to manifest higher levels of power.

This law is innovative in institutionalizing selective waste collection, in recognizing the recyclers (catadores) as important social actors in solid waste management, and in promoting shared responsibility, through sector accords and reverse logistics. The law requires every municipality to develop their own solid waste management plan, besides plans on the regional and inter-municipal levels. The law foresees specific funding possibilities for municipalities to be able to access the resources required to upgrade their waste management plants. The law further reiterates the hierarchy in waste treatment from not generating, reducing, reusing disposed products, to recycling and composting and final disposal of waste at landfills.

Several challenges are given with the new legislation, including monitoring its application and adjusting the legislation to the reality of the catadores. This means to guarantee the recognition of recyclers as professional category and insert the catadores in the reverse logistics. The Government will have to be the facilitator in the dialogue between recyclers and industries.

The participation of organized recyclers is mentioned various times throughout the legislation. Article 40, highlights the need to prioritize contracts with recycling coops or associations in the selective collection of waste and in the implementation of reverse logistics. Article 41 and Article 42, guarantee the contemplation of organized recyclers in the city's waste management plan and reassure addressing the needs for these groups to participate in the implementation of the programs and actions defined under that plan. The federal government needs to regulate specific programs to improve the working conditions of the recyclers and to generate opportunities for their social and economic inclusion, according to Article 43. Recyclers' organizations are exempt of the bidding process (Article 44).

The initiatives highlighted under Article 42 will be benefitted by:

- fiscal, financial and credit incentives;

- $\quad$ availability of public land;

- directing the solid waste from federal public institutions to recycling coops, as defined under the Decrete \# 5940/20063;

\footnotetext{
${ }^{3}$ Presidência da República. Casa Civil Subchefia para Assuntos Jurídicos, Decreto No. 5940, 25.09.2006, Available from http://www.planalto.gov.br/ccivil_03/_Ato20042006/2006/Decreto/D5940.htm
} 
- $\quad$ economic subsidy;

- setting criteria, aims and other complementary forms to seek environmental sustainability during the implementation of public contracts;

- $\quad$ payment for environmental services;

- support in the definition of clean development mechanism projects or any other mechanism based on the UN climate convention.

Furthermore, Article 81 highlights the fact that federal funding institutions may create specific funding lines to support coop recycling, by facilitating the acquisition of equipment used in solid waste management.

Nevertheless, there are also some serious flaws to the law. Shortly before sanctioning the law a significant alteration in the wording of Article 9, Paragraph 1 was made, allowing for incineration as WfE to play a more prominent role. Originally the text read: "Technologies that recover energy from waste can be used if their technical and environmental viability has been proven and with a system in place to monitor gas emissions, approved by the environmental agency". Originally the sentence continued with the following wording, restricting the use of incineration ..."after all other waste management possibilities, mentioned earlier have been exhausted" (Art. $9 \S 1^{\circ}$ ) (Translated by the author). By taking away this part of the sentence a change in hierarchy now allows for incineration as an energy recovery measure, even before reuse, composting and recycling has been performed.

Furthermore, under Article 58 the law excuses governments from including catadores in waste management, when the existing recycling organization is inefficient or for some reason presents public health hazards. Unfortunately most of the recycling coops and associations still perform their work under precarious and often unhealthy conditions. Many recycling groups, particularly those that are not supported by local governments are still extremely vulnerable, with inefficient infrastructure, weak administration, lack of organization, and low remuneration. With little or no backing from the government, their operations are often not viable, generating very low income (sometimes half a minimum salary ${ }^{4}$ ) and as a consequence there is a high fluctuation rate of participant recyclers. If by any means the government declares that the existing coop does not have the capacity or are considered economically inefficient to participate in the selective waste collection, then the groups can be excluded.

Another important social shortcoming of the new legislation is the fact that autonomous recyclers are excluded as participants in resource recovery. Similarly there is also no mentioning of the role of scrap dealers who usually buy the material recovered from the autonomous recyclers. With the new law in place informal recyclers will be twice excluded, since most of them already barely survive from the payment of the recyclable materials. There is no reference as to how these catadores could be included in waste management in the future.

\section{Conclusion}

Not only does incineration and energy recovery from waste cause environmental hazards, but it also dismisses the fact that resource recovery and recycling schemes are more socially and environmentally friendly than simply burning the materials. Recycling generates a large

${ }^{4}$ One Minimum Salary is currently 540.- R\$ or 325.- US\$ (March 30th 2011). 
amount of employment and contributes to resource conservation. Recovering recyclable materials generates net carbon credits, which should be redirected to those who are engaged in the collection, separation and recycling of waste. Recycling could also tap into 'Carbon gaining funds' because that is what reuse and recycling does. Such a measure would be more socially and environmentally just and, at the same time, it would also contribute to addressing poverty reduction, one of the Millennium Development Goals.

The prevailing mainstream discourse and general dominant politics, however, still support the growth oriented economic development model, understanding progress as unlimited growth. This dominant view perceives resources as limitless and defends the rational that there will always be unrecyclable waste as a result of production and consumption. Consequently, the large quantity of rejected material and the growing demand for energy are seen as justification for the implementation of incinerators as energy generating plants. As an alternative path, however, participatory sustainable waste management (PSWM) translates into the networking among different stakeholders and the construction and strengthening of solid waste management policies with the inclusion of the recyclers, aiming at social equity and environmental sustainability. This form of management is based on the principles of social economy, valuing and empowering the recyclers, aiming at reducing, reusing and recycling; addressing responsible consumption and refusing the waste of resources. Few examples demonstrate that this path can be viable, despite many difficulties still have to be overcome. Cities like Diadema and Londrina are experimenting with PSWM and have achieved important results towards resource recovery.

There is an eminent need to address the challenge of reducing waste generation. It is a given that most municipalities in the global North and also now in the global South are threatened by a shortage of landfill capacity. It is also common sense that the fact that environmental damage can be caused by inappropriate waste management needs to be addressed. In addition, concerns regarding global warming and resource depletion related to production and consumption are looming at the horizon. It is essential to adopt a cyclical materials flow approach. Waste for energy is not a cyclical process, since the material dies with incineration. Participatory sustainable waste management facilitates the cyclical use of resources, generates work and employment and cares for the environment and future generations. Further insights are needed to explore the potential of resource recovery to promote a paradigm shift towards zero waste and the formation of more sustainable societies.

\section{References}

ABRELPE (Associação Brasileira de Empresas de Limpeza Pública e Resíduos Especiais) (2007). Panorama dos resíduos sólidos no Brasil 2007. ABRELPE. São Paulo

Agdag, O. N. (2009). Comparison of old and new municipal solid waste management systems in Denizli, Turkey. Waste Management, Vol.29, No.1, January 2009, pp. 456464

Ahmed, S. A. \& Ali, M. (2004). Partnerships for solid waste management in developing countries: linking theories to realities. Habitat International, Vol.28, pp. 467-479

Bai, R., \& Sutanto, M. (2002). The practice and challenges of solid waste management in Singapore. Waste Management, Vol.22, No.5, pp. 557-567

Brasil (Ministério das Cidades) (2009). Plano Nacional de Saneamento Básico. Brasília: Secretaria Nacional de Saneamento Ambiental, Ministério das Cidades. Available 
from http://www.cidades.gov.br/ministerio-das-cidades/arquivos-e-imagensoculto/TR_PanoramaSaneamentoBrasil_PLANSAB.pdf

Britannica Online Encyclopedia, (n.d.). Materials processing, Available from http://www.britannica.com/EBchecked/topic/369072/materials-processing

CEMPRE (Compromisso Empresarial para Reciclagem) (2010). CEMPRE, São Paulo, Available from http://www.cempre.org.br/ciclosoft_2010.php

DEFRA (Department for Environment, Food and Rural Affairs) (2006). Review of England's Waste Strategy A Consultation Document February 2006. Department for Environment, Food and Rural Affairs, London, Available from http://www.defra.gov.uk/environment/waste/strategy/review/documents/revi ew-consult.pdf

DEFRA (Department for Environment, Food and Rural Affairs) (2007). Waste Strategy for England 2007, Available from http://www.defra.gov.uk/environment/waste/strategy/

DEFRA (Department for Environment, Food and Rural Affairs), Partnership UK \& 4ps (2009). Waste Infrastructure Delivery Programme Information Note on Combined Heat and Power (Information note)

Department of Trade and Industry (2007). Meeting the Energy Challenge A White Paper on Energy. May 2007. TSO (The Stationary Office), UK, Available from http:/ / www.dti.gov.uk/energy/whitepaper/page39534.html

EEA (European Environmental Agency) (2009). Waste and material resources, Available from http://www.eea.europa.eu/themes/waste

Gohlke, O. \& Martin, J. (2007). Drivers for innovation in waste-to-energy technology. Waste Management Research, Vol.25, No.3, pp. 214-219

Granato, F. (2011). DIÁRIO SP, Meio Ambiente 03/02/2011, Available from http://www.diariosp.com.br/index.php?id=/dia_a_dia/sao_paulo/materia.php\& cd_matia $=27902$

Gutberlet, J. \& Takahashi, N. (2007). Avaliação rápida da coleta seletiva porta a porta do Programa Vida Limpa em Diadema. Participatory Sustainable Waste Management Project São Paulo. (Report)

IBGE (Instituto Brasileiro de Geografia e Estatística) (2010). Censo populacional, Available from http:/ / www.censo2010.ibge.gov.br/dados_divulgados/index.php?uf=35

Institution of Mechanical Engineers (n.d.). Energy from waste A wasted opportunity? (Report), Available from http://www.imeche.org/Libraries/Rita/Energy-from-Waste_ Report_1.sflb.ashx

Klein, N. (2008). The shock doctrine. New York, Metropolitan Books

Larkin, G. R. (1994). Public-private partnerships in economic development: A review of theory and practice. Economic Development Review, Vol.12, pp. 7-9

Longden, D., Brammer, J., Bastin, L. \& Cooper, N. (2007). Distributed or centralised energyfrom-waste policy? Implications of technology and scale at municipal level. Energy Policy, Vol.35, No.4, pp. 2622-2634

Lynch, K. (1990). Wasting Away, San Francisco, Sierra Club Books

Maximo, L. (2011). PPPs surgem como saida para manejo do lixo urbano., Clipping Planejamento \& Valor Econômico. 15.02.2011, Available from http:/ / www.oim.tmunicipal.org.br/ ?pagina=detalhe_noticia\&noticia_id=28511 
Mougeot L. J. A., (2005). Agropolis: The Social, Political and Environmental Dimensions of Urban Agriculture. London, Earthscan

MNCR (Movimento Nacional de Catadores de Materiais Recicláveis) (2010). Available from www.mncr.org.br/

Ongondoa, F. O., Williams, I.D. and Cherrett, T.J. (2011). How are WEEE doing? A global review of the management of electrical and electronic wastes. Waste Management, Vol.31, No.4, pp. 714-730

Persson, A. (2006). Characterizing the Policy Instrument Mixes for Municipal Waste in Sweden and England. European Environment, Vol.16, pp. 213-231

Pinto, T. de P. \& González, J. L. R. (2008). Elementos para a organização da coleta seletiva e projeto dos galpões de triagem. Ministerio das Cidades \& Ministerio do Meio Ambiente. Brasilia

Rocha, G., (2009). Diagnosis of Waste Electric and Electronic Equipment Generation in the State of Minas Gerais. Fundacao Estadual do Meio Ambiente (FEAM), Governo Minas, Minas Gerais, Brazil, Available from <http:/ / ewasteguide.info/Rocha_2009>

Sjöström, M. and Östblom, G. (2010). Decoupling waste generation from economic growth - A CGE analysis of the Swedish case. Ecological Economics, Vol.69, No.7, pp. 15451552

Suzuki Lima, R. (2007). Resíduos sólidos domiciliares. Um programa de coleta seletiva com inclusão social. Brasília, Programa de Modernização do Setor Saneamento, Secretaria Nacional de Saneamento Ambiental, Ministério das Cidades, Governo Federal

Talyan, V., Dahiya, R. P., \& Sreekrishnan, T. R. (2008). State of Municipal solid waste management in Delhi, the capital of India. Waste Management, Vol.28, pp. 1276-1287

Turan, N. G., Coruh, S., Akdemir, A., \& Ergun, O. N. (2009). Municipal solid waste management strategies in Turkey. Waste Management, Vol.29, No.1, pp. 465-469

Vyhnak, C. (2008). Durham region approves huge garbage incinerator. The Toronto Star, Jan. 24, 2008, p. A15

Yates, J. S. \& Gutberlet, J. (2011a). Enhancing livelihoods and the urban environment: The local political framework for integrated organic waste management in Diadema, Brazil. Journal of Development Studies, Vol.47, No.4, pp. 1-18

Yates, J. S. \& Gutberlet, J. (2011b). Re-claiming and re-circulating urban natures: Integrated organic waste management in Diadema, Brazil. Environment and Planning A, (accepted 11.03.2011) 


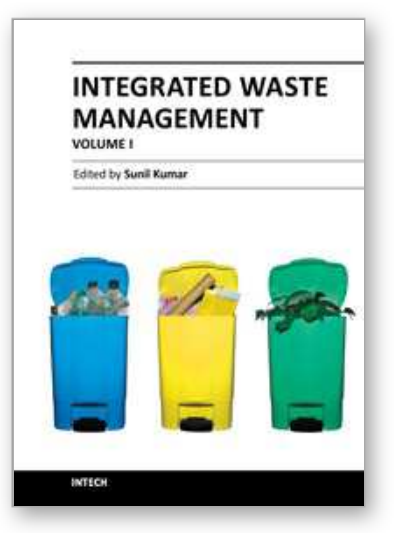

\author{
Integrated Waste Management - Volume I \\ Edited by Mr. Sunil Kumar
}

ISBN 978-953-307-469-6

Hard cover, 538 pages

Publisher InTech

Published online 23, August, 2011

Published in print edition August, 2011

This book reports research on policy and legal issues, anaerobic digestion of solid waste under processing aspects, industrial waste, application of GIS and LCA in waste management, and a couple of research papers relating to leachate and odour management.

\title{
How to reference
}

In order to correctly reference this scholarly work, feel free to copy and paste the following:

Jutta Gutberlet (2011). Waste to Energy, Wasting Resources and Livelihoods, Integrated Waste Management - Volume I, Mr. Sunil Kumar (Ed.), ISBN: 978-953-307-469-6, InTech, Available from:

http://www.intechopen.com/books/integrated-waste-management-volume-i/waste-to-energy-wastingresources-and-livelihoods

\section{INTECH}

open science | open minds

\section{InTech Europe}

University Campus STeP Ri

Slavka Krautzeka 83/A

51000 Rijeka, Croatia

Phone: +385 (51) 770447

Fax: +385 (51) 686166

www.intechopen.com

\section{InTech China}

Unit 405, Office Block, Hotel Equatorial Shanghai

No.65, Yan An Road (West), Shanghai, 200040, China 中国上海市延安西路65号上海国际贵都大饭店办公楼 405 单元

Phone: +86-21-62489820

Fax: +86-21-62489821 
(C) 2011 The Author(s). Licensee IntechOpen. This chapter is distributed under the terms of the Creative Commons Attribution-NonCommercialShareAlike-3.0 License, which permits use, distribution and reproduction for non-commercial purposes, provided the original is properly cited and derivative works building on this content are distributed under the same license. 